DOI: $10.15290 / \mathrm{bsl} .2018 .12 .14$

\author{
Martyna Miernecka \\ Instytut Kultury Polskiej \\ Uniwersytet Warszawski \\ e-mail: martyna.miernecka@op.pl \\ ORCID: 0000-0003-2854-6155
}

\title{
„Wyjechałem w inny świat". Miron Białoszewski w przestrzeni uzdrowiska (Zawat, Konstancin, Listy do Eumenid)
}

Miron Białoszewski przeżywa pierwszy zawał serca w 1974 roku. „Właściwie już wiem, że muszę zrezygnować natychmiast $\mathrm{z}$ wielu rzeczy" $\left(\mathrm{Z}^{1}\right.$, s. 5) - brzmi jego pierwsza myśl w tunelu przy Marszałkowskiej, kiedy "to” go złapało. Infarctus myocardii stanowi niewątpliwą cezurę w biografii poety. Nie tylko musi on zrezygnować $\mathrm{z}$ wielu dawnych przyzwyczajeń, związanych z funkcjonowaniem chorego ciała ${ }^{2}$, lecz także stawić czoła wielu nowym tematom i miejscom. Doświadczenie zawału serca znajduje wyraz w dokonaniach artystycznych Białoszewskiego, przyczyniając się do swoistego "odrutynizowania" pisania. To swego rodzaju cezura topograficzna, czyli nowy sposób przeżywania przestrzeni, odświeżenie jej percepcji. Można właściwie mówić o „zawale” w życiu Białoszewskiego i Zawale w jego twórczości.

1 M. Białoszewski, Zawał, Warszawa 1977, s. 5. W dalszej części tekstu oznaczany symbolem "Z" i numerem strony, z której pochodzi fragment. Wykaz innych skrótów: AAA - M. Białoszewski, Obmapywanie Europy. Aaameryka. Ostatnie wiersze, Warszawa 1988; SzZC - M. Białoszewski, Szumy, zlepy, ciagi, Warszawa 1976; K - M. Białoszewski, Konstancin, Warszawa 1991; LdE - M. Białoszewski, Listy do Eumenid, w: tegoż, Tajny dziennik, Kraków 2012.

2 Oczywiście, nie są to jedyne zmagania Białoszewskiego ze zdrowiem, które - co kluczowe - za każdym razem opisuje w utworach: w Miejscowości wniosku z Rachunku zachciankowego poeta relacjonuje leczenie gruźlicy w Otwocku, w Spotkaniach z nożem - problemy urologiczne, ponadto tworzy utwory typu Pótpasiec - noga - ząb. Sprawozdanie z tryptyku chorobowego... z Donosów rzeczywistości. Jednak od 1974 roku zawał staje się stałym „bohaterem” jego utworów, w przypadku Zawału, Konstancina i Listów do Eumenid - głównym. 
W związku z obecnością licznych, interesujących analiz zarówno szczegółów topograficznych przestrzeni rekonwalescencji ${ }^{3}$, jak i cielesnego doświadczenia choroby ${ }^{4}, \mathrm{w}$ swojej interpretacji skupię się na zmysłowej percepcji miejsc sanatoryjnych, wykorzystując koncepcję Tadeusza Sławka dotyczącą genius loci. Analizę poprzedzę refleksją nad tym, co "przed” chorobą $\mathrm{i}$ „po" niej - to znaczy z jakim nastawieniem Białoszewski wyrusza do sanatorium i jak te wyjazdy na niego wpływają.

\section{„Cała ta uzdrowiszczyzna byłaby nie bardzo do zniesienia": przedsanatoryjnie}

Choroba wpływa zarówno na tematykę, jak i poetykę utworów Białoszewskiego, stanowiąc przede wszystkim nowy materiał literacki, jak się wydaje, niezwykle ważny i cenny - nie bez powodu poetę przed wyjazdem do sanatorium martwi głównie to, czy na temat ludzi z rządowego sanatorium będzie mógł coś ciekawego napisać. Już w uzdrowisku nie chce przeprowadzić się do jednoosobowego pokoju, bo mu się „żal zrobiło dialogów" [Z, s. 147]. Odmienność i specyfikę miejsca poznaje poprzez język: „Dom nazywa się tu oddział” [K, s. 8], "Salowe nazywają się tu pokojowe" [K, s. 8], a nową dla siebie przestrzeń oswaja dzięki rozmowom z Jadwigą, wspominającą jedną z konstancińskich willi. Przychylniej patrzy bowiem na miejscowość spersonalizowaną za sprawą opowieści przyjaciółki ${ }^{5}$. Czerpie z nich informacje, które następnie należy „sprawdzić sobą", ocenić, co zgadza się z wcześniejszymi wyobrażeniami, a co zaskakuje czy rozczarowuje oraz co wynika ze zderzenia oczekiwań z zastaną przestrzenią. Białoszewski eksperymentuje $z$ metodami poznawania nowego miejsca ${ }^{6}$, a także monitoruje możliwe odpowiedzi na pytanie o to, kim sam w nim jest.

3 Zob. A. Kobelska, W poszukiwaniu straconego miasta. Nieczarodziejska Królewska Góra: Konstancin, w: Tętno pod tynkiem, red. A. Karpowicz, W. Pessel i in., Warszawa 2013.

4 M.in.: J. Brzozowski, Wiersze ostatnie Mirona Białoszewskiego, w: Pisanie Białoszewskiego. Szkice, red. M. Głowiński, Z. Łapiński, Warszawa 1993; W. Jajdelski, Symbolika czystości i brudu w twórczości szpitalnej Mirona Białoszewskiego, „Pamiętnik Literacki” 1999, z. 3; I. Janicka, Starzy poeci, "Podteksty” 2008, nr 4, http://podteksty.amu.edu.pl/podteksty/?action=dynamic\&nr=15\& dzial=4\&id=335 [dostęp 21.12.2018]; K. Pietrych, "Jak podejść do siebie"?, w: tejże, Co poezji po bólu. Empatyczne przestrzenie lektury, Łódź 2009; S. Rosiek, Pamiętnik z pótgrobu, w: Pisanie Białoszewskiego.

5 A. Kobelska, W poszukiwaniu straconego miasta, s. 65.

6 Małgorzata Czermińska wyróżnia dwa sposoby oswajania przestrzeni przez Białoszewskiego w podróży. Oprócz wcześniejszej wiedzy na temat danych miejsc, badaczka wskazuje na układ odniesienia, czyli porównywanie nowych przestrzeni do tych znajomych. Ten sposób nie 
Zawał oznacza konieczność ukształtowania nowej tożsamości - tożsamości, która, w przypadku Białoszewskiego, jest w ogromnej mierze formowana przez przestrzeń Warszawy. Stolicę pisarz traktuje jako środowisko naturalne, oczywiste dziedzictwo ${ }^{7}$ zaspokajające potrzebę intymności i poczucia bezpieczeństwa. Ponadto swojemu miastu przeciwstawia przede wszystkim przestrzeń natury: „Nie jestem dzieckiem natury. Mam w sobie jeszcze tę XVII-wieczną niechęć do marszczonego od wiatru błota i do podjeżdżającego na zimnie zawiewu zielska, mam tak jak mój Ojciec, a Ojciec po Dziadku, pęd do miasta, do hałasu i tłoku" [SzZC, s. 177].

A zatem: korzenie Białoszewskiego tkwią w centrum Warszawy i sięgają podwarszawskich miejscowości, jest poetą miasta. Ta przestrzenna determinacja "ja" nasila się w późnej twórczości, gdy następuje pęknięcie między przestrzenią oswojoną a obcym, nowym miejscem. Najczęściej pęknięcie to interpretowane jest $\mathrm{w}$ kontekście przeprowadzki autora w 1975 roku z placu Dąbrowskiego na Saską Kępę (znaną z utworów jako Chamowo). Mówiąc o "poetyckiej bezdomności Mirona Białoszewskiego" od momentu przeprowadzki ${ }^{8}$, należy pamiętać także o jego doświadczeniach sanatoryjnych i zadać pytania o sposoby radzenia sobie z tymi nieznanymi obszarami, których mityczność - dodajmy - potęgowana jest poprzez specyficzne archiwum kultury.

"Wyjechałem w inny świat", powie Białoszewski. Statusowi sanatorium jako „innego świata”, budowanego na podstawie znaczeń związanych z europejską kulturą uzdrowiskową Białoszewski jest niechętny. To, co dla ludzi dziewiętnastowiecznych stanowiło jedno z ważniejszych zjawisk społeczno-kulturowych - w uzdrowiskach bywano, bo bywać należało, o nich się mówiło, a także pisało - przez Białoszewskiego zostanie nazwane nieznośną „uzdrowiszczyzną". Charakter miejsca, jego historyczno-kulturowy status sięgający metafizycznych przesłanek lecznictwa uzdrowiskowego, jak i obowiązujące $\mathrm{w}$ nim regulaminy, zgodnie $\mathrm{z}$ którymi "tu pilnują schodzeń, leków, jedzeń" [K, s. 41], czyni z niego pole konfliktowych napięć.

Model ośrodków sanatoryjnych w Polskiej Rzeczpospolitej Ludowej $\mathrm{z}$ jednej strony nawiązywał do dziewiętnastowiecznego, elitarnego typu francuskiego, przeznaczonego dla najbogatszych warstw europejskiego mie-

jest częsty w tekstach sanatoryjnych, pojawia się za to w niezwykłym natężeniu w AAAmeryce: "Cisza. Jak w Sieradzu [...] Domy wielkie, ale cicho i pusto. Jak w Przasnyszu" [AAA, s. 59]. Zob. M. Czermińska, Małe i wielkie podróże Mirona Białoszewskiego, w: Pisanie Białoszewskiego, s. 86.

7 A. Legeżyńska, Dom Mirona Białoszewskiego, w: Pisanie Białoszewskiego, s. 62-63.

8 I. Janicka, Starzy poeci. 
szczaństwa, związanego z potrzebą splendoru, z drugiej natomiast - do stylu wypoczynku wyższych warstw społecznych w carskiej Rosji przed 1914 rokiem. Karykaturalne przekształcenia sprawiły, że specyfika pobytu w PRL-owskim sanatorium polegała przede wszystkim na połączeniu reżimu sanitarnego i nieformalnej praktyki życia codziennego. Sanatoria stały się placówkami o charakterze biesiadno-ludycznym, w których - jak się wydaje trudno było się odnaleźć Mironowi Białoszewskiemu. Ponadto uzdrowiska sytuowane są w szczególnego rodzaju miejscowościach, które nie mogą być ani wsią, ani miastem ${ }^{9}$. To miejsca wymagające specjalnego zagospodarowania, łączącego naturę z przestrzenią miejską (domy zdrojowe, bulwary, ulice, kawiarnie, sklepy, lokale rozrywkowe):

Istnieje pewien schemat przestrzenny uzdrowiska, w ramach którego G. Balińska wyróżnia 4 obszary: 1 . znajdujący się w centrum plac zdrojowy, 2. sięgający obszarów leśnych park zdrojowy z małą architekturą, 3. wkomponowany w środowisko naturalne obszar mieszkalno-pensjonatowy oraz 4. leśną zieleń stanowiącą naturalną otulinę miejscowości.

I dalej:

Rozwój przestrzeni turystycznej sprawia, że wiele miejscowości (w tym uzdrowiskowych) traci swój indywidualny charakter na rzecz ugrzecznionej, wyczyszczonej przestrzeni miejskiej, która stanowi rodzaj bańki środowiskowej dla turystów, a jednocześnie barierę pomiędzy nimi a życiem lokalnych mieszkańców ${ }^{10}$.

Powyższe cechy charakterystyczne rozwijających się miejscowości uzdrowiskowych nabiorą innych, nieco zaskakujących znaczeń w kontekście sposobu waloryzowania przestrzeni przez Mirona Białoszewskiego. Naturalna, zielona otulina miejscowości okaże się raczej przekleństwem, potęgującym tęsknotę twórcy za życiem miejskim. Niewątpliwie jednak zależy mu na tym, aby bańka środowiskowa - zawierająca to, co „wyczyszczone” i „ugrzecznione" - pękła. Zdaje się, że rozbicie tej bańki stanowi główny cel poety w czasie kuracji.

Problematyczne okaże się też „uzdrowiskowe” archiwum kultury obejmujące najważniejsze kody, reprezentacje, wzorce ujmowania przestrzeni w dziełach związanych z tematyką "sanatoryjną" i ich normy gatunkowe,

9 G. Balińska, Kreacja przestrzeni uzdrowiska dawniej i dziś, w: Zdroje Ziemi Kłodzkiej. Historia, przyroda, kultura, przyszłość, red. W. Ciężkowski, J. Dębicki, R. Gładkiewicz, Wrocław 2000, s. 51.

${ }_{10}$ Ł. Braun, Teoretyczne aspekty rozwoju kultury uzdrowiskowej w perspektywie antropologii kulturowej ze szczególnym uwzględnieniem antropologii podróży, w: Kultura uzdrowiskowa na Dolnym Ślasku w kontekście europejskim, red. B. Płonka-Syroka, A. Kaźmierczak, Wrocław 2013, t. 1, s. 80. 
tworzące "nieuchwytne genius loci”, ,auratyczność”, ,duchowość”, ,widmowość" ${ }^{\prime 1}$. Jeśli potraktować Czarodziejska górę Tomasza Manna jako wzór tekstu, w którym kumuluje się sanatoryjna pamięć kultury, małe narracje Białoszewskiego stoją wobec niej w opozycji. Jego Konstancin czy Inowrocław są pozbawione kontekstu kulturowego Davos - to czyste prowincje. Białoszewski nie kreuje hermetycznej, zmitologizowanej atmosfery pensjonatu dla chorych, w którym dokonuje się edukacja duchowa bohatera; nie aspiruje do budowania monumentalnej refleksji społeczno-politycznej, wreszcie - kładzie, w przeciwieństwie do Manna, istotny nacisk na znaczenie realnej topografii i przekazanie indywidualnego doświadczenia, wydobywającego konkretność danych miejsc.

\section{„I tak się nauczyłem jeździć, chociaż to nadal jest heca”: posanatoryjnie}

Zapowiedzią trwałego zwrotu - zawału i Zawału, które odkryją w Białoszewskim chęć spotkania z nowymi miejscami - jest już sam wybór uzdrowiska:

- Konstancin wiadomy

- nudny

- pod Warszawą

- Inowrocław niewiadomy

- zupełnie nieznany [Z, s. 110].

Decydującym czynnikiem okazuje się możliwość otwarcia na inne przestrzenie niż (pod)warszawskie. Po „epizodzie” uzdrowiskowym świadectwem zasadniczej przemiany jest decyzja o podróży statkiem wokół Europy, a także pobyt w Stanach Zjednoczonych: „Właściwie to dobrze. Na razie żadnych pułapek. Dziwne. Przyjechałem tu po nagrodę polonijną. Mogłem ją odebrać przez bank. Ale mnie kusiło" [AAA, s. 59]. Dlaczego wyprawy w nieznane nagle zaczynają być kuszące?

Niewątpliwie nie byłoby tej zmiany bez wcześniejszego trybu życia, okresu „leżeńn” w samotności, czasu przepełnionego lekturami, słuchowiskami, refleksjami, które przygotowują grunt pod przyszłe, wielkie podróże i są de facto podróżami małymi ${ }^{12}$. Tym bardziej nie byłoby nowego etapu

11 E. Rybicka, Geopoetyka. Przestrzeń i miejsce we wspótczesnych teoriach i praktykach literackich, Kraków 2014, s. 175-176.

12 Białoszewski zwraca na to uwage podczas wieczoru autorskiego na Manhattanie: „Pytają 
życia i twórczości Białoszewskiego bez przeprowadzki i kolejnych pobytów w szpitalach i sanatoriach:

- Jak to się stało, że pan wyszedł z szafy? Ja może niedobrze mówię po polsku, bo nie używam tu polskiego, ale chyba pan mnie rozumie.

- Tak, tak, doskonale - i tłumaczę mu, jak mogę, że najpierw wyrwało mnie z łóżka do szpitala, potem do sanatorium. Potem się przeprowadziłem. Dzięki temu już było łatwiej jechać do Budapesztu. A po przyjemnościach w Budapeszcie łatwiej było jechać gdzie indziej. I tak się nauczyłem jeździć, chociaż to nadal jest heca (...). Nie mogę siebie z tym wszystkim brać na serio [AAA, s. 82].

Białoszewski jest sam sobą rozbawiony. Śmieje się z siebie i otwiera na nowe doświadczenia, zwłaszcza te zmysłowe. Po pobycie $\mathrm{w}$ sanatorium zafascynowany odkrywa kopenhaskie sklepy z pornografią, żydowskie sklepy z rupieciami w Buffalo i te z płytami w Nowym Jorku. Już w Konstancinie stwierdza: "Sklepy to życie” [K, s. 25]. Często chodzi do kina: ogląda filmy pornograficzne, kryminalne, fantastyczne, science-fiction. Zaczyna nawet jeść obiady, do czego nie jest przyzwyczajony, ale, jak stwierdza, "tutaj mnie bawią" [AAA, s. 88]. Jest wręcz zachłanny: „Idziemy do domku z restauracją. Tam się nakłada jarzyn, ile się chce, za jedną cenę $\mathrm{z}$ dwunastu kotłów, bardzo to dobra rozrywka dla oka i dla języka" [AAA, s. 88].

Co sprawia, że zwolennik "leżeń" nagle zachwyca się Manhattanem, opuszcza swoje łóżko i odkrywa w sobie podróżnika? Być może nie powinno być to aż tak zaskakujące - już Maria Janion na długo przed Obmapywaniem Europy i AAAmerykq uznawała Białoszewskiego za „kapitana Cooka naszych czasów"13, dowodząc, że „topos Podróży (cóż z tego, że tramwajem lub podwarszawską kolejką) tkwi u podstaw twórczości Białoszewskiego"14. Pisarz planuje małe podróże niczym eksplorator, łowca przygód na Lesznie, Poznańskiej czy Lizbońskiej; jako odkrywca sklepów i kin z pornografią na Manhattanie - duże wyprawy. Pomiędzy danymi etapami - doświadczenie choroby i podróż do sanatorium. Pod wpływem tych doświadczeń egzystencjalno-spacjalnych relacje pomiędzy "ja" a danymi miejscami rewaloryzują się.

o moje wrażenia z Ameryki. Mówię, jak potrafię. I w ogóle o idei podróży. A potem o swoich latach leżenia w ciemnym pokoju, namysły, dziwny stan, wizje, pisania, niewychodzenia. I mówię, że to też było jak podróże, a nawet lepsze. Inni potwierdzają - Tak, to musiało być wspaniałe" [AAA, s. 81].

13 M. Janion, Życie wewnętrzne na Lizbońskiej, w: tejże, Odnawianie znaczeń, Kraków 1980, s. 253.

14 Tamże. 


\section{„Bez specjalnego nastawienia nieraz takich śmieci się nie dostrzega": zWarcie}

„Bardzo niedokładnie spojrzałem za dnia w okno” [Z, s. 152], karci się Białoszewski, uważnie badający nową przestrzeń. Jeszcze przed przeprowadzką na drugie piętro $\mathrm{w}$ inowrocławskim uzdrowisku sprawdza, jaki będzie miał widok $z$ okna. Ogląda je od strony parku. Potem patrzy na park przez okno, znajdując się $\mathrm{w}$ pokoju. Zwraca uwagę na różnicę $\mathrm{w}$ widoku między piętrami i cieszy się na nowe odkrycia. Opisuje nie tylko to, co da się zaobserwować z bliska, z perspektywy przechodnia, ale i to, co widzi z dalszej odległości, z góry. Co chwila otwiera nowe perspektywy, co może świadczyć o niepewności odczuwanej w „innym świecie”. Świat ten, skrupulatnie kreowany w małych narracjach Białoszewskiego, nie jest łatwo uchwytny, wymaga od ,ja" czujności, stawia przed nim pewne wyzwanie.

W takim ujęciu dzieło literackie staje się „dramatyzacją doświadczenia miejsca"15. "Ja" takich utworów jak Zawał i Konstancin jest otwarte na to, co niesie ze sobą proces poznawania nowej przestrzeni. Wyjazdy do uzdrowisk bohater traktuje jako swego rodzaju przygodę, jego rola jest niezwykle aktywna, ale nie mniej istotna niż sama przestrzeń, której „świadkuje”.

Białoszewski szuka w nowych miejscach gęstości: łłoku, hałasu, ruchu. Już pierwszego dnia w Inowrocławiu znajduje pretekst, by "wylecieć" na miasto, z ulgą wydostając się „z okolicy sanatoryjno-cichszej na gęstszą" [Z, s. 115]. Oswaja przestrzeń w sposób fizyczny: „I już się obleciało, obwąchało. Miało się nie wiedzieć jeszcze nic, a wie się dużo" [K, s. 11]. Chodzi, tworząc tym samym prywatną topografię - zgodnie z "białoszewską" zasadą "chodzenie to doświadczanie" 16 . Opisuje swoje trasy, aby je zapamiętać, utrwalić, a następnie zadomowić się $\mathrm{w}$ nich.

Robi wszystko, by ożywić swoje miejskie serce: „Poniosło mnie w dal ulicy głównej, bo zobaczyłem, że tam dalej autobus znów przystaje, że gęściej od ludzi, a co ważniejsze, że idą w poprzek, znikają, wynikają. Okazało się, że mają do czego i od czego" [K, s. 10-11]. Jego zapiski - szczegółowe, dynamiczne opisy o zróżnicowanym rytmie - mają za zadanie wchodzić w interakcje z żywiołowością miasteczka. Chiazmatyczne ujęcie relacji pomiędzy „ja" utworów Białoszewskiego a miejscem, w którym przebywa, wskazuje

\footnotetext{
15 E. Rybicka, Geopoetyka, s. 184.

16 A. Karpowicz, Proza życia: mowa, pismo, literatura (Białoszewski, Stachura, Nowakowski, Anderman, Redliński, Schubert), Warszawa 2012, s. 76.
} 
nie tylko na doświadczenie pisarza, który konstruuje ją literacko, lecz także na aktywną rolę miejsca.

Elementy "martwej natury" wiodą w utworze Białoszewskiego własne życie. Podmiot podkreśla ich autonomię za pomocą uosobień i animizacji. Wyjątkowo często pojawia się w „małych narracjach” motyw drogi. Jej kreacja nie jest statyczna. „Szosa się krzywi, prostuje” [K, s. 54], pisze Białoszewski w Konstancinie. W Bydgoszczy, do której udaje się z inowrocławskiego sanatorium, zachwyca się witalnością drogi, traktowanej wręcz jako nieokiełznany żywioł: „Dopiero taką ulicą krzywą, jakby skręcającą, gdzie wygodniej, wymacującą sobie bieg jak rzeka, tłumy i pojazdy płyną. Zatrzymują się po brzegach, zatykają, ruszają dalej. Nie wiadomo, gdzie wpadną" [Z, s. 177].

Kreację przestrzeni w twórczości Białoszewskiego można zinterpretować, przyjmując koncepcję genius loci Tadeusza Sławka. Oczywiście, będzie to raczej "geniuszek miejsca" [O, s. 57], o którym poeta pisze w jednym z wierszy, coś karykaturalnego i zmarniałego, sprzeciwiającego się podniosłemu "duchowi”. Nie zmienia to jednak faktu, że ,ja” w przestrzeni uzdrowiska wychwytuje coś, co może kojarzyć się z demonem, sprawującym władzę nad otoczeniem.

Genius loci to rodzaj personifikacji, „duch" wpływający na to, jak dane miejsce funkcjonuje i oddziałuje na ludzi. Charakterystyczny dla koncepcji Sławka jest podkreślany przez badacza związek podmiotu z przestrzenią, zakładający, że staje się ona partnerem bytowania ,jj"; więcej - w tej niemej „rozmowie" często okazuje się, że przestrzeń nie potrzebuje człowieka i jego porządku. Teraz ",ja" staje się "tłem" $i$ „zapleczem" miejsca ${ }^{17}$. Zgodnie z tymi założeniami, w niektórych opisach przestrzeni uzdrowiskowej u Białoszewskiego ,ja” znika. Wycofuje się. Eliminuje siebie z centrum utworu.

Miejsce może stawiać człowiekowi opór. W Konstancinie i Zawale przemocowość takiej relacji potęguje opresyjny charakter przestrzeni uzdrowiska. Białoszewski musi się z tą przestrzenią zmierzyć. Dając jej szansę na zaistnienie w roli bohaterki własnych utworów, oswaja ją. Dostosowuje swój rytm do nowego miejsca: „Na pierwszy styk z powietrzem wydawało mi się, że jest troszkę drętwo. Ale to ja byłem jeszcze troszkę drętwy. Po iluś chwilach i krokach ulice zmiękły" [Z, s. 164]. Genius loci oznacza konieczność „(a) prze-myślenia świata i mojej w nim obecności oraz (b) nieustannej pracy nad sposobami postrzegania świata" ${ }^{18}$.

17 T. Sławek, Genius loci jako doświadczenie. Prolegomena, w: Genius loci. Studia o człowieku w przestrzeni, red. Z. Kadłubek, Katowice 2007, s. 5.

18 Tamże, s. 8. 
Mimo że genius loci uzdrowiska stawia opór, mimo że czasem nie odpowiada, podmiot zyskuje jego przychylność. „Spojrzenie wywołuje na chwilę »wzajemność "świata" ${ }^{19}$, przekonuje Anna Sobolewska. Białoszewski nie pozwoli na to, żeby cokolwiek umknęło jego uwadze. Chce dostrzec każdy szczegół - na przykład napis na szyldzie, co do którego nie jest pewien, czy to nekopen, czy nekropen: „Sprawdzić. Przecież nigdy już tędy więcej mogę nie przechodzić. Sprawdziłem i zapomniałem" [K, s. 55]. Chodzi o to, by w utworze napis zaistniał i przemówił, o rejestrowanie przedmiotów, przyrody, ludzi, dawanie im i z nich świadectwa, ale nie pod własnym, pełnym władzy spojrzeniem, nie jako „właściciel”, lecz „świadek”.

Rzeczywistość u Białoszewskiego pozostaje w ciągłym ruchu. Zarówno elementy ożywione, jak i nieożywione tętnią, wibrują i krążą. Narrator jest $\mathrm{w}$ biegu, jednocześnie świat pulsuje we własnym rytmie. Ujawnienie relacji pomiędzy nimi jest możliwe dzięki wycofaniu ,ja”, które ma na celu „zespolenie" podmiotu z przedmiotem.

Interesujący wydaje się tu potencjalny wpływ kultury Dalekiego Wschodu, na który naprowadzają interpretacje Sobolewskiej. Wyimki z "małych próz" Białoszewskiego wielokrotnie przypominają haiku ${ }^{20}$. Siedemnastozgłoskowce, związane z filozofią zen, nie pozwalają na konkretną interpretację, mają pozostawiać po sobie subtelne, ulotne wrażenie. U mistrzów z Dalekiego Wschodu istotna jest poetyka niedopowiedzenia - autor nadaje tylko kierunek skojarzeniom, sugeruje to, co widz ma sobie dopowiedzieć. Stara się zatrzymać uwagę - swoją i odbiorcy - na poziomie kontemplacji, tak, by wciągnąć go $\mathrm{w}$ opisywany i przeżywany przez siebie świat. Zwięzłość wypowiedzi i oszczędne użycie środków stylistycznych, prostota, opisywanie wydarzeń kameralnych, niespektakularnych, osadzonych w codzienności, ewentualny wpływ twórczości przyjaciółki Białoszewskiego, Jadwigi Stańczakowej - to wszystko pozwala na skojarzenie fragmentów prozy autora Mylnych wzruszeń z poezją haiku.

Najciekawszą paralelą jest próba zespolenia podmiotu z przedmiotem obserwacji. Podmiot opisuje świat, ale go nie interpretuje. Powstrzymuje się przed wskazaniem pointy, co jest nie tylko dowcipnym zaskoczeniem, bliskim poezji japońskich mistrzów, ale również daje możliwość obserwacji pozbawionej intelektualnych refleksji, pozwalającej na dramatyzację samego bycia $\mathrm{w}$ danym miejscu.

19 A. Sobolewska, Lepienie widoku z domystu. Percepcja świata w prozie M. Białoszewskiego, w: Pisanie Białoszewskiego, s. 124.

20 Zob. B. Śniecikowska, Haiku? Senryū? Mironū? Poezja Mirona Białoszewskiego wobec gatunków orientalnych, „Pamiętnik Literacki” 2011, z. 3. 
W kreacji autobiograficznego ,ja" Białoszewskiego zawarta zostaje propozycja odejścia od aktywnego typu odbiorcy na rzecz takiego, który nie znajduje się $\mathrm{w}$ centrum zainteresowania, nie pełni najważniejszej roli w kształtowaniu doświadczenia estetycznego. Pod jego spojrzeniem obrazowany świat nie schodzi na dalszy plan, nie służy tylko do przeprowadzania analizy własnych uczuć i myśli. Dowartościowuje sam widok:

Wypchnęło mnie [...]. Na moją Jaworowską. Ona wieczorem albo w szare popołudnie zamienia się $\mathrm{w}$ zapatrzenie całą sobą w perspektywę. Ma twarde dno. Boki w symetrii. Siatki. Teraz wieczorem boki z niebem się schodziły. A chodniki świeciły bokami. Aż za abstrakcyjnie [K, s. 60-61].

Warto zwrócić także uwagę na kwestię przedmiotów w narracjach sanatoryjnych Białoszewskiego. Wielokrotnie pisano o statusie rzeczy $\mathrm{w}$ jego twórczości w kontekście sztuki - Stanisław Burkot fascynację przedmiotami łączył z surrealizmem ${ }^{21}$, według Anny Nasiłowskiej chodziłoby przede wszystkim o ready-made Duchampa: „przedmiot miał być anty-symboliczny i anty-estetyczny, za to dogłębnie przedmiotowy, a o nadaniu mu artystycznej rangi decydował artysta" 22 . Szczególnie istotna jest radykalna zmiana tradycyjnej funkcji przedmiotu, który w tym przypadku niczego nie oznacza. "On - jest”, przekonuje badaczka ${ }^{23}$, i dalej zwraca uwagę na konkretność przedmiotów, tryumf ich rzeczowości, spotęgowaną obecność.

Na jakie przedmioty zwraca uwagę Białoszewski $\mathrm{w}$ ramach poznawania uzdrowiskowej przestrzeni? Są to, oczywiście, sławne rupiecie ${ }^{24}$, także jako aluzje do własnej sytuacji. Na szczególną uwagę zasługują śmietniska. Poeta nie zwiedza bowiem "klasycznosanatoryjnych" zabytków, ale właśnie śmietniki w pobliskim lasku: „Ujrzałem znów śmiecie. Większe. Różności z plastiku. Dalej. Kupa szkła. Jeszcze dalej na wprost dział papierowy. Obróciłem się w lewo, a tam garnki, wiadra, czajniki, kocioł, emalie świecą. Ile tego" [K, s. 101]. Białoszewski, oglądając śmietnik, zachowuje się, jakby odwiedzał galerię sztuki. Obdarowuje to miejsce wyjątkowym spojrzeniem. Jak sam przyznaje, „Bez specjalnego nastawienia nieraz takich śmieci się nie dostrzega" [K, s. 102]. W kontekście choroby takie zdanie wybrzmiewa jeszcze mocniej: śmietnik to w końcu strefa przejścia między życiem a śmiercią,

21 S. Burkot, Miron Białoszewski, Warszawa 1992, s. 24.

22 A. Nasiłowska, Trzy krzesła, w: Pisanie Białoszewskiego, s. 194.

23 Tamże.

24 A. Sandauer, Poezja rupieci, w: tegoż, Zebrane pisma krytyczne, Warszawa 1981. 
coś o wątpliwym statusie ontologicznym, znajdujące się na granicy natury i kultury ${ }^{25}$.

\section{"A bo i ja się rozglądam. Pewnie za dużo": sensualnie}

W procesie poznawania przestrzeni uzdrowiska znaczącą rolę odgrywają zmysły. Podmiot wykorzystuje słuch (słychać postukiwanie lasek $\mathrm{w}$ drodze do ustępu, zbiorowe skrzypienie podłogi podczas gimnastyki i dźwięki krztuszących się kranów), węch (czuć na przykład śmierdzącą Jeziorkę), smak (,jedzenie to tutaj najważniejsza rzecz" [K, s. 23], powtarzają kuracjusze). Są to także tak zwane zmysły somatyczne, związane $\mathrm{z}$ receptorami $\mathrm{w}$ skórze (namacalne niemal dreszcze, które przechodzą przez pokój).

$\mathrm{Na}$ szczególną uwagę zasługuje zmysł wzroku. "Ja" uważnie ogląda sanatoryjną przestrzeń, spostrzegając na przykład kolory: „Na matowo, ale żółto. Coraz żółciej przez drzewa, od ziemi, spod nieba. Jak odbicie na szeroki świat tego żółtego budyneczku z napisem »magazyn «" [K, s. 11]. Znowu wydaje się, że podmiot patrzy nieuprzedzonym wzrokiem, omija etap interpretacji obrazów. Pozorna bierność może prowadzić do zaskakującego poszerzenia granic poznania. Chodzi o pełne skupienia patrzenie, o napięcie uwagi, przez które osoba staje się tym, na co patrzy. Według Sobolewskiej to czyste widzenie, dzięki któremu rzeczy odzyskują swoją pierwotną istotę; są tak dosłowne, że aż fantazmatyczne ${ }^{26}$, a podmiot zachwyca się nimi $\mathrm{w}$ akcie kontemplacji.

Na pierwszy rzut oka [sic! - M.M.] może wydawać się, że Białoszewski w Konstancinie i Inowrocławiu jest flâneurem. $Z$ dystansu obserwuje scenki uliczne, w niczym nie uczestniczy, czerpie przyjemność z bezcelowego - pozornie - przyglądania się. Jest samotny, ale nie istnieje bez konfrontacji z natłokiem ludzi. Rozkoszuje się obfitością wrażeń. Paradoksalnie, spojrzenie takiego podmiotu cechuje ogromna władza: flâneur widzi, ale nie jest widziany. Patrzy tak, aby nie zostać na tym przyłapanym i podporządkowuje sobie otoczenie. Kreacja „,ja" Białoszewskiego jest jednak pod tym względem odmienna. Podmiot rezygnuje ze swojej władzy, dając możliwość zaistnienia innym bohaterom. Spojrzenia zostają odwzajemnione: „Mija mnie

25 Tamże.

26 A. Sobolewska, Lepienie widoku z domystu, s. 118. 
w murowanej wyboistej bramie dziewczynka, ogląda się za mną. A bo i ja się rozglądam. Pewnie za dużo. Ale pewnie oni tu każdego oglądają. Trudno inaczej" [K, s. 92].

Jednocześnie należy zauważyć, że zmysł wzroku jest często detronizowany przez węch. Białoszewski wydaje się czuły na zapachy - perfumy gości, lawenda, pozwalająca odgrodzić się od nieprzyjemnych woni, powiewy powietrza z zewnątrz, wreszcie kwiaty i zioła, pobudzające węchową aktywność, skłaniające do porównywania, oswajania przestrzeni poprzez zapach. Węch okazuje się bardzo ważny $\mathrm{w}$ procesie poznawania tego nowego świata, a doznania z nim związane umożliwiają bezpośredni kontakt z przedmiotem. W ujęciu Białoszewskiego wzrok jest mylący, a więc poeta często sprawdza, poprawia, weryfikuje to, co ogląda. Marta Zielińska zauważa natomiast, że „niuch" traktuje on jako najmniej wątpliwe poświadczenie prawdy. „Mieć nosa, obwąchiwać - oznacza instynktownie dochodzić istoty rzeczy poza narzuconymi przez kulturę schematami", dodaje badaczka ${ }^{27}$.

Należy zaznaczyć, że zmysłowa percepcja przestrzeni zostaje zrewaloryzowana po przeżyciu drugiego zawału serca przez Białoszewskiego w 1983 roku. Powstają wówczas, w czasie pobytów poety na oddziale reanimacyjnym Szpitala Grochowskiego na ulicy Grenadierów w Warszawie i w Instytucie Kardiologii w Aninie w okresie od lutego do maja 1983 roku, Listy do Eumenid, których adresatkami są Maria Janion, Maria Żmigrodzka i Małgorzata Baranowska. Białoszewski rozpoczyna korespondencję 16 lutego 1983 roku, bezpośrednio po przeżyciu drugiego zawału, który zdecydowanie pogarsza stan jego zdrowia.

Zależność między ciałem i światem, rola ciała jako pośrednika między „ja" a rzeczywistością pozostają w Listach do Eumenid nadal niezwykle mocne. Co istotne, ciało waloryzowane jest tu inaczej - ujemnie. Staje się czymś odrębnym od ,ja", podmiot zdaje się tracić nad nim władzę i - bezwolny podporządkowuje się jego chwiejnemu rytmowi. Ciało pozostaje bezradne i bierne. Władzę nad nim mają przedmioty, podtrzymujące je przy życiu. To one są dokładnie opisywane, jak $\mathrm{w}$ pierwszym spostrzeżeniu $\mathrm{w}$ Zawale: „I dopiero tu, róg Złotej i pasażu, w palcie, taki idący uliczny, położyłem się na nosze. To była zgoda na wszystko" [Z, s. 6]. Po pierwszym zawale aktywne "ja" przezwycięża bezradność, po drugim - poddaje się. W Listach do Eumenid chory zdaje relację z zabiegów, którym poddawane jest ciało: „bez przerwy mnie oproszkowują nasennie” [LdE, s. 862], opowiada, do-

27 M. Zielińska, Białoszewski i zapachy, w: Lustra historii. Rozprawy i eseje ofiarowane profesor Marii Żmigrodzkiej z okazji pięćdziesięciolecia pracy naukowej, red. M. Kalinowska, E. Kiślak, Warszawa 1998, s. 198. 
dając, że jest „skłuty” igłami i ma w sobie "drut” [LdE, s. 862]. Zabiegi są zdecydowanie brutalne, a chory - mimo sympatii personelu - jest traktowany przedmiotowo, nie do końca świadomy, co się z nim dzieje.

Podłączenie do szpitalnej aparatury „pozbawia poczucia niezależności, a wręcz tożsamości. Trudno bowiem określić, czy urządzenia, do których podłączony jest pacjent, stają się częścią jednej biologicznej całości, czy też nasilają dezintegrację ciała" ${ }^{28}$. Duży nacisk położony na aspekty medyczne - druty, igły, zastrzyki, piguły - świadczy o potrzebie oswojenia sytuacji i zmniejszenia poczucia dezorientacji.

$\mathrm{Ta}$ „cielesna opresja choroby manifestuje się w samym sposobie percypowania rzeczywistości”, jak pisała Izabela Janicka ${ }^{29}$. Chory jest oglądany, ale zakres jego własnego pola widzenia pozostaje niepełny. Doświadczenia zmysłowe, poprzez które mógłby poznawać przestrzeń choroby, zostają zminimalizowane. Perspektywa, z jakiej ogląda świat, jest ograniczona: to perspektywa szpitalnego łóżka, do którego dochodzą wybrane odgłosy aparatury, intensywne światła, widok nóg innych pacjentów. Leżący na wznak pacjent jest pozbawiony władzy. Ponadto, nie może uchronić się przed nieprzyjemnymi wrażeniami - tak, jak przed agresywnymi dźwiękami, które w końcu go pochłaniają. Chcąc nie chcąc, musi słuchać jęków umierających czy transmisji w przenośnym telewizorze współlokatora sali szpitalnej. To „audialne odczucie bycia wśród innych”, jak pisze Karpowicz ${ }^{30}$, w tym wypadku nie tworzy wspólnoty, lecz pozbawia intymności. Wyobcowany ze znanej audiosfery, Białoszewski próbuje - zgodnie ze swoim zwyczajem strukturyzować nową przestrzeń właśnie poprzez dźwięk. Ale dźwięki szpitali i uzdrowisk są chaotyczne i nie pozwalają na „zawiązywanie się współbycia przez ucho" ${ }^{31}$. Poeta pozostaje obcy i nie może odnaleźć się w szpitalnym i uzdrowiskowym życiu publicznym: „,...] Chłopy odwiedzają się, dobrze się z sobą czują, ja - nie bardzo. Nie mam co z nimi gadać. Nie chce mi się ich. W młodości byłem przystosowywalniejszy. Czym starszy - tym mniej" [LdE, s. 873].

Jakkolwiek oba pozawałowe doświadczenia Białoszewskiego radykalnie się od siebie różnią, znamienne jest podobieństwo relacji pomiędzy ,ja” a przestrzenią. Podmiot w ujęciu Białoszewskiego użycza miejscom swoich emocji i skojarzeń, natomiast sama przestrzeń jest sprawcza, determinuje stan zdrowia i psychikę chorego, co za tym idzie - sposób jej postrzegania i cha-

\footnotetext{
28 E. Winiecka, Białoszewski sylleptyczny, Poznań 2006, s. 127.

29 I. Janicka, Starzy poeci.

30 A. Karpowicz, Proza życia, s. 60.

31 Tamże, s. 70.
} 
rakter opisu. Chiazmatyczne połączenie ,ja” i przestrzeni pozwala uspójnić doświadczenie - orientować się w obcej topografii i szukać w niej egzystencjalnego oparcia.

Analizowane utwory Mirona Białoszewskiego stanowią próbę dyskursywizacji doświadczenia choroby. Odpowiedzi na pytania dotyczące bohatera: „co robi?”, ,jak?”, „dlaczego?” i wreszcie: „gdzie?" ukazują specyfikę procesu oswajania przestrzeni chorowania przez Białoszewskiego. W opisach specyficznych sanatoryjnych ośrodków podkreślona zostaje perspektywa podmiotu mówiącego, który nie tylko rejestruje przestrzeń, ale też obserwuje własne w niej istnienie, rytm własnego ciała. Ważny okazuje się także kontekst kulturowy, w którym "ja" funkcjonuje; charakter miejsca i sposób, w jaki się o nim opowiada; sprawczość miejsc i ich zmienność.

Pobyty w sanatoriach i szpitalach oraz ich literackie kreacje składają się na kolejne etapy budowania tożsamości przez Białoszewskiego. W procesach tych z jednej strony współuczestniczy rzeczywistość, z drugiej - tekstowe ,ja", w specyficzny sposób posługujące się wpływem, jaki miejsce na nim wywiera. Białoszewski usiłuje odnaleźć siebie samego, na nowo tworzyć własne ",ja", w każdym akcie percepcji kształtować je od nowa. Analiza Zawału, Konstancina i Listów do Eumenid dowodzi, jak ważna w każdym z tych aktów była przestrzeń uzdrowiska i szpitala.

\section{Bibliografia}

Balińska Grażyna (2000), Kreacja przestrzeni uzdrowiska dawniej i dziś, w: Zdroje Ziemi Kłodzkiej. Historia, przyroda, kultura, przyszłość, red. W. Ciężkowski, J. Dębicki, R. Gładkiewicz, Wrocław: Uniwersytet Wrocławski. Centrum Badań Śląskoznawczych i Bohemistycznych, Muzeum Ziemi Kłodzkiej.

Białoszewski Miron (1991), Konstancin, Warszawa: Państwowy Instytut Wydawniczy. Białoszewski Miron (2012), Tajny dziennik, Kraków: Wydawnictwo Znak.

Białoszewski Miron (1988), Obmapywanie Europy. Aaameryka. Ostatnie wiersze, Warszawa: Państwowy Instytut Wydawniczy.

Białoszewski Miron (1976), Szumy, zlepy, ciagi, Warszawa: Państwowy Instytut Wydawniczy.

Białoszewski Miron (1977), Zawał, Warszawa: Państwowy Instytut Wydawniczy.

Braun Łukasz (2013), Teoretyczne aspekty rozwoju kultury uzdrowiskowej w perspektywie antropologii kulturowej ze szczególnym uwzględnieniem antropologii podróży, w: Kultura uzdrowiskowa na Dolnym Ślasku w kontekśsie europejskim, t. 1, red. B. Płonka-Syroka, A. Kaźmierczak, Wrocław: Wydawnictwo Questio. 
Burkot Stanisław (1992), Miron Białoszewski, Warszawa: Wydawnictwa Szkolne i Pedagogiczne.

Jajdelski Wojciech (1999), Symbolika czystości i brudu w twórczości szpitalnej Mirona Białoszewskiego, „Pamiętnik Literacki”, z. 3, s. 95-106.

Janicka Izabela (2018), Starzy poeci, „Podteksty” 2008, nr 4, http://podteksty.amu. edu.pl $/$ podteksty $/$ ?action $=$ dynamic\&nr $=15 \&$ dzial $=4 \& i d=335$.

Janion Maria (1980), Życie wewnętrzne na Lizbońskiej, w: tejże, Odnawianie znaczeń, Kraków: Wydawnictwo Literackie.

Karpowicz Agnieszka (2012), Dary. Miron Białoszewski, w: tejże, Proza życia: mowa, pismo, literatura (Białoszewski, Stachura, Nowakowski, Anderman, Redliński, Schubert), Warszawa: Wydawnictwo Uniwersytetu Warszawskiego.

Pietrych Krystyna (2009), "Jak podejść do siebie"?, w: tejże, Co poezji po bólu. Empatyczne przestrzenie lektury, Łódź: Wydawnictwo Uniwersytetu Łódzkiego.

Pisanie Białoszewskiego. Szkice (1993), red. M. Głowiński, Z. Lapiński, Warszawa: Wydawnictwo IBL PAN.

Rybicka Elżbieta (2014), Geopoetyka. Przestrzeń i miejsce we wspótczesnych teoriach i praktykach literackich, Kraków: Universitas.

Sandauer Artur (1981), Poezja rupieci, w: tegoż, Zebrane pisma krytyczne, Warszawa: Państwowy Instytut Wydawniczy.

Sławek Tadeusz (2007), Genius loci jako doświadczenie. Prolegomena, w: Genius loci. Studia o człowieku w przestrzeni, red. Z. Kadłubek, Katowice: Wydawnictwo FA-art.

Śniecikowska Beata (2011), Haiku? Senryū? Mironū? Poezja Mirona Białoszewskiego wobec gatunków orientalnych, „Pamiętnik Literacki”, z. 3, s. 77-111.

Tętno pod tynkiem. Warszawa Mirona Białoszewskiego (2013), red. A. Karpowicz, P. Kubkowski, W. Pessel, I. Piotrowski, Warszawa: Lampa i Iskra Boża.

Winiecka Elżbieta (2006), Białoszewski sylleptyczny, Poznań: Wydawnictwo „Poznańskie Studia Polonistyczne".

Zielińska Marta (1998), Biatoszewski i zapachy, w: Lustra historii. Rozprawy i eseje ofiarowane profesor Marii Żmigrodzkiej z okazji pięćdziesięciolecia pracy naukowej, red. M. Kalinowska, E. Kiślak, Warszawa: Wydawnictwo IBL PAN.

Zieniewicz Andrzej (1989), Przeprowadzki - pisanie jako dom, w: tegoż, Małe iluminacje. Formy prozatorskie Mirona Białoszewskiego, Warszawa: Państwowy Instytut Wydawniczy.

\section{"I left for a different world". Miron Białoszewski in a health resort (The Heart Attack, Konstancin, The Letters to Eumenides) \\ Summary}

The article presents the way of domesticating the space of the health resort and hospital in three works of Miron Białoszewski: The Heart Attack, Konstancin and The Letters to Eumenides. The illness - in 1974 first and then in the year 1983, second heart attack - forces the writer to stay consecutively 
in unfamiliar health resorts, and at the same time it opens a new stage in his life and work. Following the assumptions of geopoetics that the way of seeing space is associated with the activity and the perception of the entity, as well as taking into account the causative role of the places, I analyze the changes occurring in Białoszewski's health resort texts. I further present the stages of constructing the "self" and demonstrate the importance of space of the health resort and hospital in each of the stages.

Keywords: literary space, genius loci, autobiographical place, illness, identity 